\title{
Precarity: The Significance of a Controversial Concept ${ }^{1}$
}

\author{
ELENA GASIUKOVA, OVSEY SHKARATAN \\ Laboratory for Comparative Analysis of Post-Socialist Development, National Research University Higher School of Economics, \\ Myasnitskaya, 13/4, Moscow, Russia, 101000 \\ Email: lena-gasyukova@yandex.ru; ovsey.shkaratan@gmail.com
}

\begin{abstract}
The authors focus on the category of precarity that refers to the phenomenon of dynamic instability resulting from income fluctuation and frequent job changes. Precarious workers view their situation as deviating from the norm and standards of living typical of their immediate circles. Thus, the term precarity describes a situation which is beyond the scope of the labour market and not confined to categories representing non-standard employment relations. As both objective and subjective parameters need to be taken into consideration in precarity studies, the conceptualisation of the phenomenon should not be subject to rigid universalist categories. Identification criteria prove to be contextual. The authors are convinced that the term precarity denotes a fundamentally new phenomenon not reduced to employment insecurity situations of the past. The article demonstrates that it is wrong to equate the modern situation of precarity with the position of an exploited proletarian worker, as the structural components of the labour market have changed, and the experience of the previous generation has affected the development of employment standards used as a benchmark today. The concept of precarity refers to a phenomenon without any precedents in the past and is highly relevant for studying modern labour markets.
\end{abstract}

Keywords: precarity, instability, ambivalent subjectivity, de-standardization, labor careers, employment insecurity

The swiftness, versatility and inconsistency of social processes in the modern world are a challenge for academics: 'liquid modernity' (Bauman 2013) passes through the sieve of legitimized formalized concepts, leaving the researcher with lifeless scholastic abstractions and classifications that do not offer any insights. Bauman points out that the available knowledge and categories are not helpful in capturing the essence of things, but the need for understanding is pressing: we can no longer look at the social reality with managers' eyes, trying to mould people and things into a shape they would obediently take, in compliance with a cultural scenario (Bauman 1994). The heterogeneity and ambiguousness of social issues suggest the necessity of reconsidering the scope of understanding a society's life and the departure from axiomatic premises. Particularly prominent is the departure from universalist tools.

1 The study was implemented in the framework of the Basic Research Program at the National Research University Higher School of Economics (HSE) in 2018. 
Ongoing debates about the validity of sociological indicators and the relevance of their underlying concepts demonstrate the ambiguity of categories and classifications used by modern authors. On the one hand, researchers are faced with the challenge of suggesting such tools that would enable them to capture the essence of the examined social phenomenon; on the other hand, the proposed conceptualization needs to be as free from subjectivism as possible and be understood and used unambiguously. A prime example of such a debatable concept is precarity. This concept is notable, because it is formed at the intersection of the objective and the subjective, which is one of the reasons for its ambiguous interpretation and operationalisation.

An individual's precarious status is characterized by instability originating from a multitude of sources. First of all, this instability results from an individual's volatile job situation and financial vulnerability. Today, there are a number of similar categories at researchers' disposal (for instance, informal or non-standard employment, flexibilisation), but they describe only the employment type. At the same time, some authors regard precarity as subjective experience of instability, an ontological state as opposed to precariousness which is a structural characteristic of an individual's employment situation (Ridout, Schneider 2012; Arnold, Bongiovi 2013; Gill, Pratt 2008). We share the latter view and believe that the precarity phenomenon should not be restricted to employment relations (this idea will be elaborated below), although we take into consideration that a job is the main source of income and life prospects for the majority of people.

Since the 1990s, the discussion about the problem of uncertainty/vulnerability/instability of employees has become firmly established in the academic discourse: researchers pointed to the risks of reduced social assistance from the government and the necessity of withstanding the challenges of modernity without any minimum guarantees (Willborn 1997; Cappelli, Bassi, Knoke, Katz, Osterman, Useem 1997); more often these questions arose as a result of an individual's job insecurity. At the same time, commonly used concepts referring to the labour market position (including unemployment) were not able to capture/represent the situation of existential instability. Therefore, researchers turned to the new concept of precarity, in order to denote the volatility of the modern worker's social position. Other authors, by using the notion of precarity, referred to the development of a new political force among workers opposing the erosion of the welfare state and the loss of former labour rights (Neilson, Rossiter 2008; Casas-Cortés 2014). Overall, the majority of articles on precarisation/precarity highlighted necessary inputs into public policy for improving the life of vulnerable people.

In the present article, we will address the conceptualisation of precarity, pointing out the difficulties resulting from its attempted operationalisation, and will provide our own vision of this phenomenon. Our goal is to show that precarity is an original concept representing an underexplored phenomenon typical of the modern stage of labour relations and the current political situation. This conceptualisation refers to a certain life situation previously not denoted by a separate term. In this regard, we aim to demonstrate that the concept of precarity describing the situation of existential instability should not be reduced to already known concepts from the realm of labour relations, on the one hand, and to show that the phenomenon described by this notion is historically unprecedented, on the other hand.

\section{THE CONCEPTUALISATION OF PRECARITY}

As the instability of an individual's position can arise from two main sources, the environment and the worker's subjectivity, two stances on the nature of precarity can be found in 
literature: one deals with objective factors and the realm of labour relations, while the other, additionally, has the subjective perception of vulnerability as its main criterion. 'Precarious workers of the first type' occupy vulnerable positions on the labour market, with their instability determined by the presence, content, and enforcement of a labour contract; 'precarious workers of the second type' hold a social position that is hard to maintain under the constant risk of failure. These two stances not so much contradict each other as capture different aspects of the phenomenon. Speaking in a less abstract way, with regard to reality as such, precarity, according to the first interpretation, reflects the restructuring of labour relations, the growing share of non-standard forms of employment characterized by more individualized employment contracts and terms of employment, reduced employment protection, and broader informal agreements (McKay, Jefferys, Paraksevopoulou, et al. 2012); as per the second interpretation, precarity refers to a life situation of the dynamic instability that prevents an individual from predicting income flows and future employment status in the short term, as well as to the resulting lack of confidence in one's ability to maintain the usual lifestyle and make plans for the future (Dörre 2014; Ridout, Schneider 2012: 5-9; Arnold, Bongiovi 2013; Gill, Pratt 2008; Armano, Murgia 2013: 486-501²). These two stances on precarity are interrelated: non-standard employment is often accompanied by income fluctuations, unforeseen project termination or dismissal, a gap between expectations and the existing achievements of precarious workers. The second approach suggests a stricter definition of precarity, as it is determined both by subjective and objective factors. It should be clarified that precarity is not a synonym for job insecurity, ${ }^{3}$ since it not only implies the subjective anxiety regarding keeping one's social status but also requires the actual experience of living under the conditions of instability when individuals attempt to have the usual lifestyle (pursuing hobbies, having the familiar circle of friends, making and implementing plans, maintaining good health), but objective material conditions and an unstable job limit their options and can force them to give up consumption typical of their lifestyle.

We adhere to the second position, believing that the concept of precarity should characterize a phenomenon beyond the scope of the labour market, not limited to categories referring to individuals' non-standard forms of employment. The employment type describes the work (labour) organization of special-type employees (for example, self-employed) or relations with the employer (for example, informal relations) but, admittedly, says nothing about the instability of the employee's social and economic situation. Informally employed workers do not have recognized legal rights, employment guarantees, and proper labour conditions, ${ }^{4}$ but their labour relations with an employer may last a long time and bring stable income. Or, as for self-employment, we can say that only workers are responsible for

2 Armano and Murgia (2013) use the reverse terminology: precarity refers to the working sphere, while precariousness characterises the experience/situatedness of insecurity and uncertainty.

3 The concept of job insecurity is defined as the perceived threat of job loss and the worries related to that threat (De Witte 2005).

4 Here, we rely on the following definition of informality: employees are considered to have informal jobs if their employment relationship is, in law or in practice, not subject to national labour legislation, income taxation, social protection or entitlement to certain employment benefits (advance notice of dismissal, severance pay, paid annual or sick leave, etc.) (Hussmanns 2004). See also: Hussmanns, R. 2004. Measuring the Informal Economy: From Employment in the Informal Sector to Informal Employment. Policy Integration Department, Bureau of Statistics, International Labour Office; Kapelyushnikov 2012. 
their employment organisation or risks; ${ }^{5}$ however, their business can be successful and bring a steady high income, in which case their situation cannot be characterized as precarious.

The above-mentioned definition of precarity can hardly be interpreted unambiguously, it has a heuristic nature. There are several aspects that lead to possible confusion when operationalising the concept in empirical studies.

As stated above, the precarity situation is largely caused by unstable employment and income (Fuller 2009). At the same time, precarity does not mean poverty: more often, the precarity phenomenon is ascribed to those whose income is within a certain medium range, not low enough for slipping into poverty but at the same time not sufficient to build up savings for several months ahead.

Not all workers who 'hop' from one job to another end up in a situation of precarity. Irregular employment does not necessarily lead to income fluctuations and an unstable social status (Standing 2016). An example here would be casual employment of a housewife or steady side jobs of a student. Although some authors write about the vulnerability of the modern youth (Kretsos 2010), the life stage when a student juggles study and work can hardly be described by the term 'precarity'. For many students, a side job is just an opportunity to have extra pocket money. Typically, they are supported by parents and do not need to take care of a family or accommodation. This leads us to the idea of contextuality of precarity.

Both objective and subjective indicators of labour market security are to some extent unreliable, as they often rely on universalist categories most commonly used by researchers (Kiersztyn 2017). That is why, for the purposes of studying precarity, situations under examination should be specified, taking into account the particular features of the environment and the individual's personal characteristics. Those include, among others, the access to alternative career paths, human capital, stage of the life course, help from family (Campbell, Price 2016), as well as macro-level parameters, such as the government's generosity in providing social assistance. ${ }^{6}$

The criterion of voluntary/forced unstable employment cannot be used to delineate precarity, either: a defensive psychological response 'can convince' individuals that the existing situation of instability is ultimately their voluntary decision (Pouliakas, Theodossiou 2010); and, conversely, having a stable job and an average or higher than average salary, individuals may believe that they work out of necessity, not being able to leave their jobs and start doing what they really love for various reasons (for example, family). Moreover, when assessing their security, individuals may look to the reference group status (Kiersztyn 2017), which also highlights the role of local factors. In the situation of precarity, individuals see their status as deviating from the norm, not meeting the living standards typical of their immediate circle. That is why we can talk about the situation of precarity among, for example, academic workers (when the lack of funds prevents them from matching the social expectations of their immediate circle), while not assigning this characteristic to residents of favelas (when destitute people share the poverty of others rather than stigmatize it) (Munck 2013).

5 Self-employment is defined as individuals who perform some work for profit or family gain, in cash or in kind (Le 1999; Measuring Self-employment in the United States). Typically, a self-employed individual is someone who is the sole worker organizing his or her employment and work process independently (https://www.gov.uk/working-for-yourself; Gruber, Poterba 1994).

6 There is a wide variation regarding the risk of precarious working by Member State (Precarious Employment in Europe, 2016). 
Thus, the concept of precarity captures a certain situation of existential instability that cannot be described just by the commonly used terms denoting labour status; contextual characteristics should be taken into account when formalising this situation. ${ }^{7}$ But then a question arises as to why researchers need to go to the trouble of discarding the existing tools and performing a complicated operationalisation of the precarity concept. To a large extent, this can be explained by the fact that the examined phenomenon is new and cannot be boiled down to the life experience of past generations; this assumption, however, needs to be reviewed separately.

\section{THE PRECARITY NOVELTY'S DISCUSSION}

The question of whether the status of the modern worker differs from that of the past remains debatable: some tend to think that the diversification of employment types and workers' unstable situation represent a new stage in the history of labour relations (Armano, Bove, Murgia 2017), others are convinced that the period of state-backed labour market security is an exception and covers a rather short time span, approximately from the 1950s through the late 1970s (Dubal 2017; Neilson, Rossiter 2008), when the countries of Western Europe and the United States followed the welfare state policy that provided employment guarantees to citizens. As for insecure work underlying the development of precarity, it was prevalent for the most part of the 19th and 20th centuries. From this point of view, the modern stage of employment relations is characterized by a return to the historically prevalent lack of employment guarantees.

An author's position on the issue will depend on how he or she views the image of the precarious worker. If the same characteristics are assigned both to present-day precarious workers and the working class of the 19th century, ${ }^{8}$ then authors imply that there is nothing new in the situation of precarity. At the same time, these researchers opposing precarity novelty develop their arguments differently, using opposite traits to describe precarious workers. For example, Han (Han 2018) believes that employment vulnerability and insecurity are typical of workers both in the present and the past. What is common between modern-day precarious workers and the lumpenproletariat (from the perspective of Marx and Engels) is the lack of class consciousness and a unifying identity preventing them from joining forces in order to fight for their labour rights. Neilson and Rossiter (2008) concur with the idea that precarity is not a new phenomenon, but at the same time they believe it is the antagonistic attitude and the desire to ally against employers' exploitation that characterize present-day precarious workers and workers of the past. As state-backed employment security diminished, previous employment relations standards controlled by the government were modified, although not in favour of employees, and the conflict between employees and employers intensified again. That is why Neilson and Rossiter (2008) tend to view precarious workers as a political force whose interests are not that different from demands put forward by workers in the past.

7 In this section, we did not cover the issue of gender discrimination which requires a careful examination of its own. For more details see Maestripieri 2015.

8 It is no coincidence that the concept of 'precariat' was formulated by analogy with the proletariat (Standing 2011); however, further consideration of the precariat as a new social class received criticism: opponents of the precariat concept argued against the social homogeneity of the 'newly obtained' class, the theoretical consistency of its identification criteria (Wright 2016; Paret 2016; Mills 2014), as well as its novelty (Choonara 2011). 
However, we do not agree with Han (2018) and Neilson, Rossiter (2008). In our opinion, when comparing the situation of precarious workers in the present and in the 19th century, authors leave out two important aspects - the previous employment experience and the de-standardisation of labour market trajectories.

\section{THE SITUATION OF POST-FORDISM}

The historical past does not vanish without a trace: the previous experience of protected employment (development of a safety net for workers and the relevant legislative framework, supply of decent jobs from employers and creation of a political system for insuring the population against risks) shapes the labour relations standards that workers are guided by today. Labour relations meeting these standards are seen as the norm, irrespective of the statistical prevalence at a given time. For instance, young graduates who entered the labour market in the 1990s and 2000s expected to land decent, steady jobs that would match their education level; however, they encountered difficulties, trying to find satisfying work. Munck (2013) emphasizes that the discourse of precarity, as established by G. Standing, operates within the 'labourist' framework; that is, the concept of precarity opposes the image of a social democratic state, full employment, and the whole corporatist bargaining apparatus. In the case of the 19th-century proletariat, we see no such opposition; in other words, the situation of precarity and mistreatment of workers suggest different contextual macro-situations, different temporal planes in which the tension produced by the inconsistency between actual and ideal employment conditions becomes apparent.

These macro-situations, one may say, differ in the sense that in the situation of precarity there is a discrepancy between the new developing forms of employment relations (and respective practices) and the habitual dispositions imposed by the family, the education system, and other institutions that have their own momentum. In the previous situation of industrial mass production, this gap was missing: workers accepted available employment conditions as they had no other standards to evaluate them against. The modern situation, to use Bourdieu's terms, is characterized by hysteresis (Bourdieu 1990: 62-63), when workers keep elements of habitus that were formed in the past but need to be modified under the new conditions. At the same time, this discrepancy has a double effect: some workers rely on the ideas of the past and fail to 'fit into' the current type of employment relations; on the other end of the spectrum are those who are able to take advantage of non-standard employment and see the benefits of flexible work that were not available before (Kesisoglou, Figgou, Dikaiou 2016; Fournier, Bujold 2005).

Thus, the previous generation's experience of guaranteed employment determines the main difference in the proletariat's and the precariat's perception of their employment situation. The precarity phenomenon is characterized by retrospective evaluation, comparison between the present and the past. In the modern situation, the actual mechanisms of labour market do not match the practical beliefs about its functioning in the past. A reaction to this inconsistency manifests itself in numerous demonstrations and strikes ${ }^{9}$ which prove that Fordist views are relevant for the present generation of workers.

9 For example: Tens of Thousands of Public Sector Workers Strike Across France. Available at: https://www.theguardian.com/world/2018/mar/22/thousands-of-public-sector-workers-go-on-strike-across-france; Amazon Workers Strike in Germany, Joining Action in Spain and Poland. Available at: https://www.reuters. com/article/us-walmart-cvs/cvs-walmart-resolve-pharmacy-contract-impasse-idUSKCN1PC17R 


\section{NOT BACKGROUND, BUT PERSONAL DECISION}

When comparing the positions of the working class in the past and the precariat in the present, one needs to bear in mind that the employment situations of both subjects differ in terms of potential career opportunities (Cartmel 2007). The labour market of the past is characterized by homogeneity of jobs and similarity of employment relations. As for the modern stage, there exists a variety of possible career paths and employment types. This heterogeneity results from expanding geography of labour markets, free migration of workers between countries, increasing share of the service sector in the job market, and blurring of boundaries between the segments of prestigious, high-skill jobs and routine, low-skill ones (Kalleberg 2009). The modern worker has access to new, flexible types of employment and diverse professional niches. Although these transitions between professional fields are not always voluntary and are not always possible, one can speak about modern workers' choices and intentions which affect the successfulness and forms of their career trajectories.

Poverty and exploitation had a unifying effect on workers, as their solidarity was based on common hardships. On the contrary, production decentralization and differentiation result today in a lack of common views and demands among workers in the situation of precarity (Trott 2013). This heterogeneity is in evidence when workers assess their situation (see below), as well as choose a career trajectory. Nowadays, the whole gamut of career options is available. Alongside full-time secure jobs still prevalent in Western labour markets, unstable career trajectories with their characteristic income fluctuations and alternating employment types are also common. Some individuals, for instance, intentionally choose boundaryless careers (Furlong, Cartmel 2006: 7) (that is, create 'choice biographies'), not confining themselves to one workplace, occupation, or organisation.

In the modern employment environment, the role of reflexivity is important: workers' interest, pursuit of professional self-actualisation, willingness to be responsible for their own employability underlie the subjective perception of their situation (for example, these trends are defined by authors as protean career orientations (Hall 2004) or portfolioability (Goncharova, Krupets, Nartova, Sabirova 2016). But this growing decision-making trend can lead to ambivalence in workers' self-evaluation of career prospects and a weaker negotiating position (Turrini, Chicchi 2013).

Proletarians' main demands regarding their situation improvement had to do with higher wages and fewer hours, whereas precarious workers cannot state their claims as clearly. Professional trajectories of precarious workers are too heterogeneous for a joint demand agenda that would cater to all of their needs. The subjective decisions to become a precarious worker may have many reasons and result in different situations. For some people, a conscious choice to leave the corporate environment is behind the volatility of their current life situation, for others it is a possibility to avoid unemployment. Another group of workers view their situation as a transitional phase on their way towards landing a 'good job', while allowing 2 to 10 years for this period of precariousness (Kesisoglou, Figgou, Dikaiou 2016; Gasiukova, Korotaev 2017).

Thus, we cannot state that the positions of the precariat and the proletariat are similar. Their employment situations are not comparable, in particular, because these groups work under structurally different conditions: modern workers often need to be flexible and reflexive, whereas proletarians have to bend to circumstances. Today, career trajectories are more heterogeneous and less determined by the starting point. On the one hand, modern workers hope for professional success and acknowledge the value of a free choice. On the other hand, 
they admit that it is their own decision to opt for a stable or unstable path. There is a 'paradox of modern subjectivation between subordination and empowerment, between regulation and freedom' (Lorey 2006) when personal choice becomes the top priority, while employment security is the price to be paid for this freedom of choice.

\section{CONCLUSIONS}

In this article, the concept of precarity is examined as a category denoting a situation of volatility caused by an insecure labour market position (Tsianos, Papadopoulos 2006; Düll 2004). The category of precarity makes it possible to capture the idea of dynamic instability when the previous professional experience of a worker determines the existing uncertainty about his or her future and inability to maintain the usual lifestyle. Thus, both objective and subjective components of instability are taken into account in precarity studies, which is why the concept of precarity is barely susceptible to rigid formalisation.

The authors demonstrate in this article that the phenomenon of precarity is a distinctive characteristic of the modern stage of employment relations. It is shown that a worker's subjective perception of his or her position is taken into consideration when discussing the situation of precarity. On the one hand, workers can compare their current situation with reference groups. On the other hand, they evaluate their situation against previously prevailing views on standard employment relations. This comparison implies a hindsight analysis of the position of workers with similar career prospects in the past. Thus, precarity also reflects a certain intertemporal conflict (tension), an inconsistency between expectations and real conditions that intensifies today when the role of agency in addressing or choosing important life issues is increasing. Hence, studying the concept of precarity shows that in order to identify or describe the employment and social position of a modern worker, one needs to apply conceptualisation relevant to the given time period and factoring in the local aspects of labour relations regulation. Universalist categories in this case cannot absorb the essential characteristics of the phenomenon described through the perception of one's own deviation from the subjectively established norm.

Received 21 February 2019 Accepted 6 June 2019

\section{References}

1. Amazon Workers Strike in Germany, Joining Action in Spain and Poland. Available at: https://www. reuters.com/article/us-walmart-cvs/cvs-walmart-resolve-pharmacy-contract-impasse-idUSKCN1PC17R (cited 20.12.2018).

2. Armano, E.; Murgia, A. 2013. 'The Precariousnesses of Young Knowledge Workers: A Subjectoriented Approach', Global Discourse 3(3-4): 486-501.

3. Armano, E.; Bove, A.; Murgia, A. 2017. 'Hybrid Areas of Work in Italy: Hypotheses to Interpret the Transformations of Precariousness and Subjectivity', in Mapping Precariousness, Labor Insecurity and Uncertain Livelihoods. Routledge, 59-71.

4. Arnold, D.; Bongiovi, J. R. 2013. 'Precarious, Informalizing, and Flexible Work: Transforming Concepts and Understandings', American Behavioral Scientist 57(3): 289-308.

5. Bauman, Z. 1994. 'Spor o postmodernizme', Sociologicheskij zhurnal 4 (in Russian).

6. Bauman, Z. 2013. Liquid Modernity. John Wiley \& Sons.

7. Bourdieu, P. 1990. The Logic of Practice. Stanford University Press.

8. Campbell, I.; Price, R. 2016. 'Precarious Work and Precarious Workers: Towards an Improved Conceptualisation', The Economic and Labor Relations Review 27(3): 314-332.

9. Cappelli, P.; Bassi, L.; Knoke, D.; Katz, H.; Osterman, P.; Useem, M. 1997. Change at Work. Oxford University Press on Demand. 
10. Cartmel, F. 2007. 'Social Change and Labour Market Transitions', in Young People and Social Change: New Perspectives. Open University Press, 34-52.

11. Casas-Cortés, M. 2014. 'A Genealogy of Precarity: A Toolbox for Rearticulating Fragmented Social Realities In and Out of the Workplace', Rethinking Marxism 26(2): 206-226.

12. Choonara, E. 2011. 'Is There a Precariat?' Socialist Review. October.

13. De Witte, H. 2005. 'Job Insecurity: Review of the International Literature on Definitions, Prevalence, Antecedents and Consequences', SA Journal of Industrial Psychology 31(4): 1-6.

14. Dörre, K. 2014. 'Precarity and Social Disintegration: A Relational Concept', Journal für Entwicklungspolitik 30(4): 69-89.

15. Dubal, V. B. 2017. 'The Drive to Precarity: A Political History of Work, Regulation, \& Labor Advocacy in San Francisco's Taxi \& Uber Economics', Berkeley Journal of Employment and Labor Law 38: 73.

16. Düll, N. 2004. 'Defining and Assessing Precarious Employment in Europe: a Review of Main Studies and Surveys' Economix 10(12): 2013.

17. Fournier, G.; Bujold, C. 2005. 'Nonstandard Career Trajectories and Their Various Forms', Journal of Career Assessment 13(4): 415-438.

18. Fuller, S. 2009. 'Chapter 14. Investigating Longitudinal Dimensions of Precarious Employment', in Gender and the Contours of Precarious Employment. London: Routledge, 226.

19. Furlong, A.; Cartmel, F. 2006. Young People and Social Change. UK: McGraw-Hill Education.

20. Gasiukova, E.; Korotaev, S. 2017. Precariousness in Russia: Attitudes, Work and Life Experience of Young Adults with Higher Education. Series WP BRP 'Basic Research Program'. National Research University Higher School of Economics, 73.

21. Gill, R.; Pratt, A. 2008. 'In the Social Factory? Immaterial Labor, Precariousness and Cultural Work', Theory, Culture \& Society 25(7-8): 1-30.

22. Goncharova, N.; Krupets, Y.; Nartova, N.; Sabirova, G. 2016. 'Russian Youth on Labor Market: 'Portfolioability' as New Desire and Demand', Studies of Transition States and Societies 8(3).

23. Gruber, J.; Poterba, J. 1994. 'Tax Incentives and the Decision to Purchase Health Insurance: Evidence from the Self-employed', The Quarterly Journal of Economics 109(3): 701-733.

24. Hall, D. T. 2004. 'The Protean Career: A Quarter-Century Journey', Journal of Vocational Behavior 65(1): $1-13$.

25. Han, C. 2018. 'Precarity, Precariousness, and Vulnerability', Annual Review of Anthropology 47: 331-343.

26. Hussmanns, R. 2004. Defining and Measuring Informal Employment. Geneva: International Labor Office.

27. Hussmanns, R. 2004. Measuring the Informal Economy: From Employment in the Informal Sector to Informal Employment. Policy Integration Department, Bureau of Statistics, International Labor Office.

28. Kalleberg, A. L. 2009. 'Precarious Work, Insecure Workers: Employment Relations in Transition', American Sociological Review 74(1): 1-22.

29. Kapelyushnikov, R. I. 2012. Neformal'naya zanyatost' v Rossii: chto govoryat alternativnye opredeleniya. Moskva: VSHEH (in Russian).

30. Kesisoglou, G.; Figgou, E.; Dikaiou, M. 2016. 'Constructing Work and Subjectivities in Precarious Conditions: Psycho-Discursive Practices in Young People's Interviews in Greece', Journal of Social and Political Psychology 4(1): 24-43.

31. Kiersztyn, A. 2017. 'Non-standard Employment and Subjective Insecurity: How Can We Capture Job Precarity Using Survey Data?' in Precarious Work. Emerald Publishing Limited, 91-122.

32. Kretsos, L. 2010. 'The Persistent Pandemic of Precariousness: Young People at Work', in A Young Generation Under Pressure? Berlin, Heidelberg: Springer, 3-21.

33. Le, A. T. 1999. 'Empirical Studies of Self-employment', Journal of Economic Surveys 13(4): 381-416.

34. Lorey, I. 2006. Governmentality and Self-Precarization on the Normalization of Cultural Producers. Available at: https://eipcp.net/transversal/1106/lorey/en (cited 10.01.2019).

35. Maestripieri, L. 2015. 'Gendering Social Vulnerability. The Role of Labor Market De-standardisation and Local Welfare', in Local Welfare Policy Making in European Cities. Cham: Springer, 51-67.

36. McKay, S.; Jefferys, S.; Paraksevopoulou, A., et al. 2012. Study on Precarious Work and Social Rights. Report for the European Commission (VT/2010/084). London: Working Lives Research Institute, London Metropolitan University.

37. Measuring Self-employment in the United States. Available at: https://www.gov.uk/working-for-yourself (cited 20.12.2018). 
38. Mills, C. 2014. 'The Great British Class Fiasco: A Comment on Savage et al.', Sociology 48(3): 437444.

39. Munck, R. 2013. 'The Precariat: a View from the South', Third World Quarterly 34(5): 747-762.

40. Neilson, B.; Rossiter, N. 2008. 'Precarity as a Political Concept, or, Fordism as Exception', Theory, Culture \& Society 25(7-8): 51-72.

41. Paret, M. 2016. 'Towards a Precarity Agenda', Global Labor Journal 7(2): 111-122.

42. Pouliakas, K.; Theodossiou, I. 2010. 'Measuring the Utility Cost of Temporary Employment Contracts before Adaptation: A Conjoint Analysis Approach', Economica 77(308): 688-709.

43. Precarious Employment in Europe: Patterns, Trends and Policy Strategies. 2016. Available at: https://pure. uva.nl/ws/files/2753967/175863_2016_Final_Publication__Precarious_Work_European_Parliament. pdf (cited 20.12.2018).

44. Ridout, N.; Schneider, R. 2012. 'Precarity and Performance: An Introduction', The Drama Review 56(4): 5-9.

45. Standing, G. 2011. The Precariat: The New Dangerous Class. London, New York: Bloomsbury Academic. 46. Standing, G. 2016. 'The Precariat, Class and Progressive Politics: A Response', Global Labor Journal 7(2): 189-200.

47. Tens of Thousands of Public Sector Workers Strike across France. Available at: https://www.theguardian.com/world/2018/mar/22/thousands-of-public-sector-workers-go-on-strike-across-france (cited 20.12.2018).

48. Trott, B. 2013. 'From the Precariat to the Multitude', Global Discourse 3(3-4): 406-425.

49. Tsianos, V.; Papadopoulos, D. 2006. Precarity: A Savage Journey to the Heart of Embodied Capitalism. Available at: https://eipcp.net/transversal/1106/tsianospapadopoulos/en/ (cited 11.03.2018).

50. Turrini, M.; Chicchi, F. 2013. 'Precarious Subjectivities Are Not for Sale: The Loss of the Measurability of Labor for Performing Arts Workers', Global Discourse 3(3-4): 507-521.

51. Willborn, S. L. 1997. 'Leased Workers: Vulnerability and the Need for Special Legislation', Comparative Labor Law \& Policy Journal 19: 85.

52. Wright, E. O. 2016. 'Is the Precariat a Class?', Global Labor Journal 7(2): 123-135.

\section{E. GASIUKOVA, O. SHKARATAN}

\section{Prekariti kaip nestabilumo sąvoka}

\section{Santrauka}

Straipsnis skirtas prekariti (angl. precarity - nestabilus egzistavimas) kategorijai apibūdinti, kuri yra svarbi dinaminio nestabilumo fenomeno, kylančio dèl dirbančiųjų pajamų svyravimo ir dažno darbo keitimo, aiškinimui. Esant prekariti situacijai darbuotojas savo padèti vertina kaip besiskiriančią nuo normos ir neatitinkančią gyvenimo standartų, kurie yra būdingi jo artimiausiai aplinkai. Prekariti - tai situacija, kuri yra už „darbo rinkos ribų“ ir kuriai apibūdinti nepakanka kategorijų, skirtų nestandartiniams darbiniams santykiams. Kadangi tiriant prekariti tenka turèti omenyje tiek objektyvius, tiek subjektyvius parametrus, tai šio reiškinio negalima griežtai ir universaliai formalizuoti. Todèl prekariti kriterijų išskyrimas yra kontekstinis. Straipsnio autoriai yra įsitikinę, kad prekariti terminas skirtas iš esmès naujam reiškiniui, kuris nebuvo būdingas darbuotojų nestabilumo aiškinimui praeityje. Jų nuomone, negalima šiuolaikinès prekariti situacijos lyginti su engiamo darbuotojo (proletaro) padetimi praeityje, nes pasikeite struktūriniai darbo rinkos komponentai, o ankstesniụjų kartų patirtis paveikè naujų darbo standartų formavimąsi. Jais ir vadovaujasi darbuotojai, vertindami savo padèti darbo rinkoje. Taigi prekariti yra reiškinys, kurio nebuvo praeityje, todèl yra aktualus tiriant šiuolaikinę darbo rinką.

Raktažodžiai: prekariti, nestabilumas, ambivalentinis subjektyvumas, nestandartiškumas, darbo karjera, užimtumo nesaugumas 